\title{
POTENTIAL USE OF ENVIRONMENTAL ISOTOPES IN POLLUTANT MIGRATION STUDIES*
}

\author{
Nada MILJEVIĆ and Dušan GOLOBOČANIN \\ Vinca Institute of Nuclear Sciences, Belgrade, Serbia \\ Received in December 2006 \\ Accepted in April 2007
}

\begin{abstract}
This article presents the use of natural abundance stable isotope (hydrogen, carbon, nitrogen, oxygen, chlorine) analysis data as a tool for providing important information about the origin of contaminants, the contribution of different sources to a multi-source plume, characterisation of their complex transport (rate and mechanisms) and for evaluating the success of contaminated site remediation. Isotopic signatures of contaminants are useful tracers of their sources, while isotopic fractionation can be used to quantitatively assess the progress of an environmental process such as biodegradation. This new isotopic approach is reliable and can offer more information than traditional techniques in pollutant migration studies, particularly after waste disposal. During biological degradation of any organic compound, molecules containing lighter isotopes are degraded, and the portion of heavier isotopes in the substrate is increased, identifying specific microbial roles in biogeochemical cycling. Since isotopic fractionation is proportional to degradation, depending on the type of contamination, a microbial degradation of $50 \%$ to $99 \%$ of the initial concentration can be quantified using isotope ratio measurements.
\end{abstract}

KEY WORDS: biodegradation, coal mining, nitrate, nitrogen, organic contaminants, stable isotopes, sulphur

The term environmental isotopes refers to isotopes, both stable and radioactive, that are present in the natural environment, either as a result of natural processes or introduced by man. Because of their specificity and reliability, environmental isotopes, namely isotopes of light elements (hydrogen, carbon, nitrogen, oxygen, sulphur, chlorine) have more extensively been used to study the global element cycles (1-3), hydrology (4-7), authentication of food and drink (8-10), medical research (11-13), and pollution monitoring $(14,15)$. Their application to trace the history of specific molecules is based on the different and distinct isotopic composition of the given molecules related to isotopic fractionation in purely

\footnotetext{
* This paper has partly been presented at the International short course: Environmental Management of Industrial Wastes in Western Balkan Countries within the EC Project "Management and Remediation of Hazardous Industrial Wastes in the Western Balkan Countries" (INDUWASTE); Zagreb, Croatia,
} 10-12 October 2006 physical processes, heterogeneous chemical equilibria and reaction kinetics caused by their origin and isotopic behaviour, as they undergo environmental processes (i.e., any process involved in the transport and fate of the contaminant in the environment, including evaporation, dissolution, volatilisation, sorption, and degradation).

Due to a consideration that greater energy is required to break bonds containing a heavier isotope (16) in an isotopically fractionating process, molecules containing a lighter isotope react at a slightly faster rate than those containing a heavier isotope. In most circumstances heavy isotope concentrates in the component in which the element is bound more strongly and thus equilibrium isotope effects usually reflect relative differences in the bond strengths of isotopes in various components of a reversible system that is in the equilibrium. If a heavier isotope concentrates in the component of interest, then that 
component is commonly referred to as enriched or heavier.

A kinetic isotope effect occurs when one isotope reacts more rapidly than another in an irreversible system or a system in which products are swept away from reactants before they have an opportunity to get into equilibrium. Normally, a lighter isotope will react more rapidly than the heavy one, and thus the product will be depleted in the heavier isotope, which is known as the kinetic isotope effect (KIE). Isotope fractionation between two compounds (e.g., a substrate, $p$, and its degradation product, $r$ ) can be expressed with the fractionation factor $\alpha$

$$
\alpha_{p-r}=\frac{R_{\text {product }}}{R_{\text {reactant }}}
$$

where $R$ is the ratio of the heavy isotope to the light isotope (e.g. ${ }^{13} \mathrm{C} /{ }^{12} \mathrm{C}$ ) of the same element in a particular molecule and often referred to as isotopic signature. The fractionation factor usually can be converted to an enrichment factor, $\varepsilon$ (in per mils, \%o) using the expression:

$$
\varepsilon=1000(\alpha-1)
$$

The classical Rayleigh-type equation for fractional distillation of mixed liquids can be written as

$$
R=R_{0} f^{(\alpha-1)}
$$

where the change in the isotopic ratio of the reactant pool, $R$, from its initial ratio, $R_{0}$, is related to the fraction of reactant remaining, $f$, by a fractionation factor, $\alpha$, which is used for KIE calculation. A detailed development of the simplified Rayleigh equation to derive isotope enrichment factor, $\varepsilon$, which is frequently used in environmental sciences, was carried out by Schmidt et al. (17)

$$
\delta_{r, t}-\delta_{r, 0}=\varepsilon \ln \mathrm{f}
$$

where $\delta_{\mathrm{r}, 0}$ and $\delta_{\mathrm{r}, t}$ are the ratios of the heavy isotope to the light isotope in the reactant $\mathrm{r}$ at time $t=0$ and $t$, respectively, expressed in the $\delta$ notation (see equation 6). Instead of the fraction remaining, the result is often presented as a fraction biodegraded, $\mathrm{B}$, in percentages (18).

$$
B(\%)=\left(1-\left(\frac{R_{t}}{R_{0}}\right)^{\frac{1}{2-1}}\right) 100
$$

The extent of biodegradation $B$ is a useful value to indicate different levels of biodegradation and can easily be converted into a quantitative value, if the source concentration for the respective sample is accessible.
Natural abundance of stable heavy hydrogen (deuterium, ${ }^{2} \mathrm{H}$ ) and oxygen-18 $\left({ }^{18} \mathrm{O}\right.$ ) isotopes as conservative tracers in water can provide preliminary indications where it came from and what happened to it on its way there (i.e. flow paths and origins of the water). When water evaporates, lighter isotopes are preferentially enhanced in vapour. During condensation of vapour to liquid, the reverse is true. The theoretical background of stable isotope fractionation in natural physico-chemical processes involving freshwater has been presented in a monograph published by the International Atomic Energy Agency (IAEA), including isotopic differences actually encountered in natural waters and their practical use for hydrological purposes (19). Variations in the isotopic composition of different waters, their isotopic "fingerprints", are used to assess the vulnerability of groundwater to pollution from the surface by determining how rapidly it moves and where it has been recharged. This improves the prediction of reactive contaminant transport in the subsurface. Synoptic and time-series sampling of solute isotope systems (e.g. carbon, nitrogen, sulphur, chloride) are potentially useful for labelling solute and pollution sources and for hydrological and biogeochemical controlling of water quality.

The threat to the environment from hazardous substances is measured by potential effects of their disposal. When wastes are land-disposed or accidental leaks and spills occur, contaminated liquid may leach from the waste and pollute groundwater. Depending on the reactivity and toxicity of the contaminants, there is a multitude of implications for both the environment and human populations. Isotope signature of pollutants is often so specific that environmental isotope methods can be used to locate the source of contamination, trace the contributions of pollutants from different sources, identify responsible polluters, and monitor the effects of efforts to limit the diffusion of a pollutant over time. This ability is used in solving problems such as landfill leaching, industrial and mine waste effluents, nutrients and pesticides, sewage disposal, overexploitation of aquifer causing induced recharge of wastewater, and monitoring the success of remediation. A particular advantage of isotope monitoring is the determination of pollutant degradation directly in the contamination plume of the hazardous waste (in situ).

This paper presents some successful current applications of stable isotope composition determination as a forensic tool to resolve sources and fates of contamination in the environment. The 
aim of this work was to illustrate principles and issues involved in stable isotope analyses, applicable to most common dissolved contaminants in groundwater.

\section{ANALYTICAL TECHNIQUES}

Variations between more and less abundant isotopes are relatively small in absolute terms and must be determined with an adequate precision and high accuracy. The appropriate measurement technique, which determines the relative natural abundance of stable isotopes in the bulk sample, is the isotope ratio mass spectrometry (IRMS) using either the dual inlet method or continuous flow (CF) system (20). IRMS instruments accept the analyte in the form of a limited number of gases $\left(\mathrm{H}_{2}, \mathrm{CO}_{2}, \mathrm{~N}_{2}, \mathrm{O}_{2}\right.$, $\mathrm{SO}_{2}, \mathrm{SF}_{6}$ ), which must be isotopically representative of the original converted sample. In the case of CF applications, these gases are introduced into the ion source by He carrier gas. The results provide only an average value of the isotope content of the individual chemical species expressed in the "delta" $(\delta)$ notation (parts per million or \%o) as the relative deviation, $\delta$, of the heavy isotope content of a sample from that of a standard according to the equation:

$$
\delta(\%)=\frac{R_{\text {sample }}-R_{\text {Standard }}}{R_{\text {Standard }}} \cdot 1000
$$

where $\mathrm{R}$ is the ratio of the heavy isotope to the light isotope in the sample (RSample) and the standard (RStandard), respectively (e.g. ${ }^{2} \mathrm{H} /{ }^{1} \mathrm{H},{ }^{15} \mathrm{~N} /{ }^{14} \mathrm{~N},{ }^{18} \mathrm{O} /{ }^{16} \mathrm{O}$, $\left.{ }^{34} \mathrm{~S} /{ }^{32} \mathrm{~S},{ }^{37} \mathrm{Cl} /{ }^{35} \mathrm{Cl}\right)$. The $\delta$ value is positive if the sample has more of the heavy isotope than the standard and vice versa. Table 1 shows the natural abundance of these isotopes and widely accepted standards. A precision of $1 \%$ o for $\delta^{2} \mathrm{H}, 0.05 \%$ o to $0.1 \%$ o for $\delta^{18} \mathrm{O}$, $\delta^{13} \mathrm{C}$, and $\delta^{15} \mathrm{~N}$, and $0.2 \%$ o to $0.3 \%$ o for $\delta^{37} \mathrm{Cl}$ and $\delta^{34} \mathrm{~S}$ is required.

Novel analytical techniques developed in the last decade, combining the molecular resolution of chromatography (GC) as pretreatment with the sensitivity of IRMS through a combustion (C) interface (GC-C-IRMS), are among the greatest advances in the determination of the isotopic composition of a single compound in a complex mixture. So-called compound-specific stable isotope analysis (CSIA) has been applied for carbon isotope measurements since 1996 (26), and has recently become available for hydrogen (27), nitrogen (28) and chlorine (29) isotope analyses. Detection limits for organic pollutants depend on preparation techniques, and are in the

Table 1 Natural abundance of stable isotope and standards in used

\begin{tabular}{lcccc}
\hline Relevant isotope ratio & $\begin{array}{c}\text { Average natural } \\
\text { abundance }\end{array}$ & Name & Absolute value & Reference \\
\hline${ }^{2} \mathrm{H} /{ }^{1} \mathrm{H}$ & $1.55 \times 10^{-4}$ & V-SMOW & 0.00015576 \\
${ }^{13} \mathrm{C} /{ }^{12} \mathrm{C}$ & $1.11 \times 10^{-2}$ & V-PDB & 0.01118 \\
${ }^{15} \mathrm{~N} /{ }^{14} \mathrm{~N}$ & $3.66 \times 10^{-3}$ & atmospheric air & 22 \\
${ }^{18} \mathrm{O} /{ }^{16} \mathrm{O}$ & $2.04 \times 10^{-3}$ & & 0.0037 & 23 \\
${ }^{34} \mathrm{~S} /{ }^{32} \mathrm{~S}$ & $4.22 \times 10^{-2}$ & V-SMOW & 0.0020052 & 21 \\
${ }^{37} \mathrm{C} /{ }^{35} \mathrm{Cl}$ & & & & 24 \\
\hline
\end{tabular}

V-SMOW - Vienna Standard Mean Ocean Water (water)

VPDB - Vienna Pee Dee Belammite (calcite)

VCDT - Vienna Canyon Diablo Troilite (FeS)

SMOC - Standard Mean Ocean Chlorine (water) 
order of $150 \mu \mathrm{g} \mathrm{L}^{-1}$ for chlorinated solvents and solid phase microextraction. With the developed purge and trap (PET) injection (30) and dynamic headspace extraction system (31), the detection limits for $\delta^{13} \mathrm{C}$ determination of volatile organic compounds (VOCs) could drastically be lowered to concentrations relevant to environmental contamination levels $\left(<5 \mu \mathrm{g} \mathrm{L}^{-1}\right)$. Greater sensitivity allows field investigations of $\mu \mathrm{g}$ $\mathrm{L}^{-1}$, which achieve concentration ranges frequently found at contaminated sites, even in the edge zones of a plume in groundwater bodies influenced by industrial point pollution (32). In general, CSIA can be used in environmental sciences for (i) allocation of contaminant sources on a local, regional, and global scale, (ii) identification and quantification of (bio)transformation reactions on scales ranging from batch experiments to contaminated field sites, and (iii) characterisation of elementary reaction mechanisms that govern product formation (17). Its several advantages over existing methods are in terms of specificity, conclusiveness, and cost-effectiveness.

\section{IDENTIFICATION OF ORIGIN AND FATE OF CONTAMINANTS IN ENVIRONMENT}

\section{Nitrate}

Natural isotopic signatures of nitrogen have been impeded by the complexity of its cycle, consisting of several pools that mix in various ways and numerous transformations with different degrees of isotopic fractionations. Nitrogen $\left(\mathrm{NO}_{3}{ }^{-}\right.$and $\left.\mathrm{NH}_{4}{ }^{+}\right)$pollution in groundwater is an important environmental problem in shallow aquifers in many countries and is increasingly becoming a threat to drinking water supplies. Potential non-point sources of nitratecontaminated groundwater include soil nitrogen, fertiliser, and animal waste. Point sources include leaky septic systems, spills or leaks, container disposal sites, fertiliser cooperatives, and animal waste storage areas. Ingestion of a high concentration of nitrates can cause many problems. It is especially dangerous for infants whose exposure to high concentrations of nitrates may cause what is commonly known as the "blue baby syndrome" with a potentially fatal outcome (33). There is also substantial evidence from animal experiments that carcinogenic $\mathrm{N}$-nitroso compounds are formed in the intestinal tract following ingestion of nitrate (34). Therefore, the US Environmental Protection
Agency and the World Health Organization (WHO) have recommended the limit for nitrate in drinking water of $10 \mathrm{mg} \mathrm{L}^{-1}$ (as $\mathrm{N}$ ) (35). A preliminary condition for prevention is to determine the origin of nitrogen dissolved in groundwater, which is either stored or denitrified in the catchments, as approximately $80 \%$ is of anthropogenic origin.

Nitrogen isotopic signatures from different sources (natural soil, fertilizer, animal waste, or sewage) are quite distinct, creating tracers that are identifiable within an ecosystem (Figure 1). Soil nitrogen has $\delta^{15} \mathrm{~N}$ values of $+5 \%$ o to $+7 \%$; nitrogen from commercial fertiliser sources has a range from $-7 \%$ o to $+8 \%$; and animal wastes are generally greater than $+10 \%$ o (36). The leaching of nitrate from soil into the groundwater depends on the soil and fertiliser type. Using mineral fertiliser, $\delta^{15} \mathrm{~N}$ value increases up to $+15.5 \%$, while the application of manure or sludge results in much higher $\delta^{15} \mathrm{~N}$ values, up to $+33.8 \%$. The increase between $+10 \%$ and $+30 \%$ o is mainly associated with human and animal activity in settlements without drainage. However, biological and chemical processes such as denitrification, nitrification, and volatilisation can alter the $\delta^{15} \mathrm{~N}$ signature, resulting in erroneous source assignment. Nitrification and denitrification are both biologically mediated. Generally, biological activities use ${ }^{14} \mathrm{~N}$ preferentially, resulting in an increased $\delta^{15} \mathrm{~N}$ value in the remaining nitrogen.

Recently developed isotopic techniques to analyse both nitrogen $\left({ }^{15} \mathrm{~N} /{ }^{14} \mathrm{~N}\right)$ and oxygen $\left({ }^{18} \mathrm{O} /{ }^{16} \mathrm{O}\right)$ isotopic fingerprints in $\mathrm{NO}_{3}\left({ }^{15} \mathrm{~N}-\mathrm{NO}_{3},{ }^{18} \mathrm{O}-\mathrm{NO}_{3}\right)$ allow us to make some deductions concerning the identification of nitrate sources and the degree of their transformations (37). Knowing oxygen and nitrogen isotope content, artificial fertilisers can be distinguished either from manure or nitrate formed from nitrification of organic material, and consequently, the dominant source of the nitrates could be identified. Denitrification is a process in which bacteria degrade nitrates $\left(\mathrm{NO}_{3}{ }^{-}\right)$to nitrogen gas $\left(\mathrm{N}_{2}\right)$, producing a distinctive isotope signature on both nitrogen and oxygen in the residual dissolved nitrate. The characteristic linear relationship between the $\delta^{15} \mathrm{~N}$ and $\delta^{18} \mathrm{O}$ values accompanied by a reduction in $\mathrm{NO}_{3}{ }^{-}$concentration confirms the occurrence of nitrate attenuation caused by microbial denitrification at aquifer site (38). A preferential enrichment of the heavy nitrogen isotope $\left({ }^{15} \mathrm{~N}\right)$ by a factor of 1.3 compared with the heavy oxygen isotope $\left({ }^{18} \mathrm{O}\right)$ is a useful means for verifying denitrification of animal waste-impacted groundwater studies (see Figure 1), $(38,39)$. Once the origin of nitrate in drinking water 


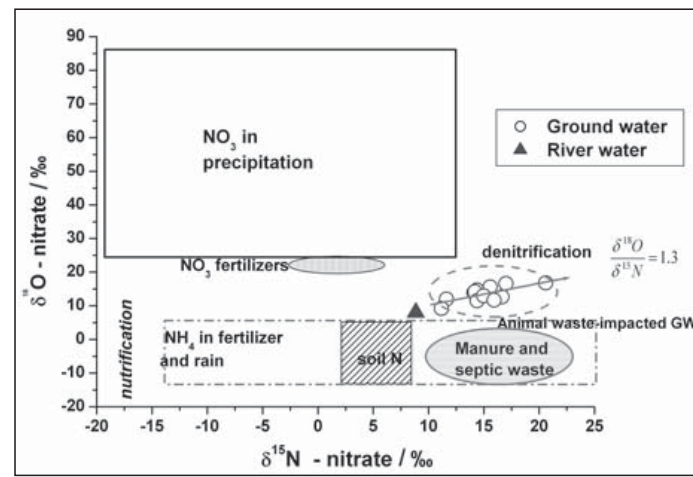

Figure 1 Isotope composition of major nitrate sources and residual nitrate dissolved in water $(38,39)$

is understood, corrective measures may be taken to prevent or minimise further contamination.

\section{Combustion residuals and coal mining waste}

The use and disposal of coal combustion byproducts (CCBs) [i.e. fly ash, bottom ash, flue gas desulphurisation material, and pressurised fluidised bed combustion (PFBC) material] at coalmines has become an area of intense interest for field applications. CCBs are generally alkaline and have $\mathrm{pH}$ values greater than 7 . One of the proposed uses of CCBs is in the reclamation of abandoned mine sites, where low $\mathrm{pH}$ and high concentrations of dissolved solids may cause significant water-quality problems. Of primary regulatory concern is the impact of soluble constituents of fly ash on the quality of surface waters and groundwaters in order to determine the influence of leachate derived from CCBs in the environment.

Wastes from energy plants and from coal mines contain sulphates, as sulphur can exist in coal and shade as pyrite $\left(\mathrm{FeS}_{2}\right)$, other metallic sulphides $(\mathrm{ZnS}$, $\mathrm{PbS}, \mathrm{FeS})$, sulphates $\left(\mathrm{FeSO}_{4}, \mathrm{Fe}\left(\mathrm{SO}_{4}\right)_{3}\right.$ or $\left.\mathrm{CaSO}_{4}\right)$, organic sulphur (not well defined), and elemental sulphur (S), which usually occurs only in trace amounts. Two primary processes responsible for fractionation of sulphur isotopes are: (i) reduction of sulphate to sulphide by the anaerobic bacteria Desulfovibrio desulfuricans, which results in a sulphide with a relatively high proportion of light isotope $\left({ }^{32} \mathrm{~S}\right)$; and (ii) exchange reactions where heavy isotope $\left({ }^{34} \mathrm{~S}\right)$ is concentrated in compounds having the highest oxidation state or greatest bond strength (40). Direct comparisons of sulphur-isotope ratios in sulphide and sulphate are possible because no significant fractionation occurs during the oxidation of sulphide minerals (41). Fractionation of sulphur isotopes upon precipitation of relatively soluble sulphate minerals is assumed to be negligible (42). Therefore, sulphur isotopic composition of dissolved sulphate as the indicator of water quality could be incorporated in groundwater monitoring programmes to detect and quantify ash-derived sulphate in local groundwater at sites where fly ash utilisation or disposal is distant from the mine site or power plant. Successful use of this parameter requires: (i) different sulphur isotopic composition of sulphate in fly ash leached and local groundwater; (ii) sufficiently oxidising condition to inhibit bacterial sulphate reduction; and (iii) conservative mixing of the two sulphate sources.

Sulphur isotopic composition of sulphate leached from fresh fly ash (emplacement site Weld County, Colorado) (43) showed strongly positive $\delta^{34} S$ values ( $+6.1 \%$ o to $+12.9 \%$ ), typical for organic bound sulphur in low sulphur $(<1 \mathrm{wt} \%$ ) coals (44). Dissolved sulphate in shallow groundwater showed negative $\delta^{34} \mathrm{~S}$ values (-2.7\% to $-3.2 \%$ o), typifying a reservoir of sulphate that originated from pyritic sulphate $\left(\mathrm{FeS}_{2}\right)$ due to bacteria-mediated sulphate reduction. Bacterial reactions favour the lighter isotope $\left({ }^{32} \mathrm{~S}\right)$, so that a fractionation was produced in going from a sulphate reactant to sulphide products. Found differences in sulphur isotope abundance permitted confident detection of as little as $10 \%$ of ash-derived sulphate in monitoring wells.

Using a sulphur-isotope ratio mixing model, relative contributions of sulphur from two different sources to water were determined at an abandoned coal mine site reclaimed with PFBC byproducts (rate of 125 tons per acre to a 7-acre, American Electric Power Tidd Plant in Brilliant, Ohio) (45). Solid-phase analysis of coal and spoil samples indicated that sulphide (mainly as $\mathrm{FeS}_{2}$ ) was the dominant sulphurbearing phase, while sulphur in the PFBC byproduct was present as sulphate, which was a result of the combustion process. The $\delta^{34} \mathrm{~S}$ value for the PFBC byproduct ranged from $+4.6 \%$ o to $+4.8 \%$ o while the spoil and aquifer-material samples had values less than $+3.2 \%$. The median $\delta^{34} S$ values in interstitial waters in the application area ranged from $-7.5 \%$ o to $-1.1 \%$ in comparison to the control area (-15.4\% to $-12.2 \%$ o). The application of isotope ratios in mixing model evaluations revealed that as much as $75 \%$ of the sulphate in interstitial waters in the application area was derived from the leaching of the PFBC byproduct.

Measurements of $\delta^{34} S$ and $\delta^{18} \mathrm{O}$ of sulphates can be applied to assess water hazard in a working coal 
mine and to identify source in discharged coal mine waters. Here is an example of isotope data used to distinguish between sulphates coming from wastes produced in power plants from the upper Silesian coal basin (southern part of Poland), where twelve coal mines are located (Fig. 2) (46). Sulphates from the fly-ashes of coal burning are enriched in heavy isotope $\delta^{18} \mathrm{O}(+23 \%$ o to $+28 \%$ o) due to higher evaporation and increasing activity of atmospheric oxygen $\left(\delta^{18} \mathrm{O}=+23.5 \%\right.$ o $)$ in the oxidation process (47). Oxygen isotopic data for sulphates of wastes from desulphurisation processes in power plants were in the range of $+13 \%$ o to $+16 \%$. Sulphates from the flotation tailings of coal mine exhibit $\delta$ values enriched with light isotope $\left({ }^{16} \mathrm{O}\right)$ of water $\left(\delta^{18} \mathrm{O}=-3.15 \%\right.$ o to $-2.32 \%$ o) used in flotation processes $\left(\delta^{18} \mathrm{O}\right.$ c $-10 \%$ ). The values for $\delta^{34} \mathrm{~S}(+4.85$ to +6.40$)$ were like those in fly-ashes of coal burning, suggesting pyrite $\left(\mathrm{FeS}_{2}\right)$ origin or minor amounts of marcasite of the Carboniferous formation. Sulphates found in some mine waters enriched with heavy isotopes, both $\delta^{34} \mathrm{~S}$ $\left(+25 \%\right.$ o to $+35 \%$ o) and $\delta^{18} \mathrm{O}(+14 \%$ o to $+19 \%$ o) suggest bacterial reduction of sulphates (48).

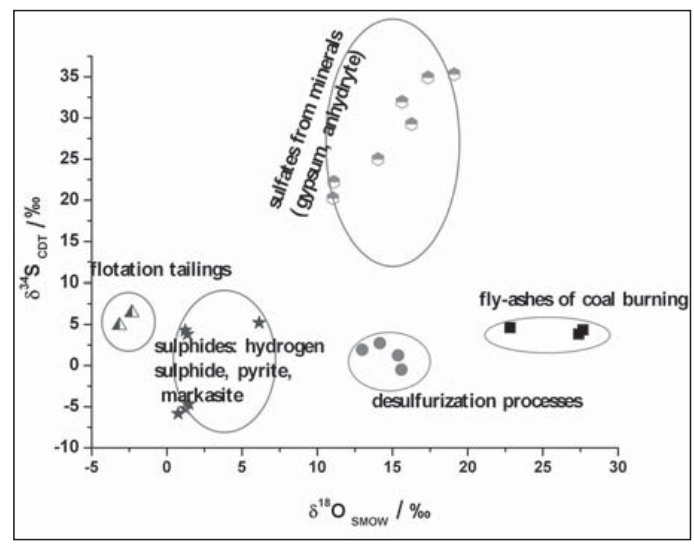

Figure 2 Plot of $\delta^{34} S$ us. $\delta^{18} \mathrm{O}$ for sulphates from mine waters of different origin in the upper Silesian coal basin, southern Poland (46)

\section{Organic contaminants}

Groundwater contaminations with organic pollutants have become a global environmental problem, especially in industrialised countries. Organic compounds are released into the subsurface in various ways (e.g. accidental spills, improper disposal methods, leaking underground storage tanks). The fate and behaviour of these compounds in the soil and groundwater media depends on a number of physicochemical and biological processes. Each process defines an independent set of compositional and isotopic changes.

The fact that stable carbon and chlorine isotope compositions of organic chemicals vary depending on the manufacturer and time-frame that they were produced (factors include the conditions and the pathways used to synthesize the compound) allows to identify sources of a chemical or to trace the time of contaminant release in the environment. This has been found for polycyclic aromatic hydrocarbons (PAHs) (49), polychlorinated biphenlys (PCBs) (50), methyl tert-butyl ether (MTBE) (51), chlorinated ethenes (52), and BTEX (Benzene, Toluene, Ethyl-benzene, Xylenes) compounds (53). In order to reliably determine that two field samples are isotopically distinct, differences in isotopic values of not less than $1.0 \%$ o (or $\pm 0.5 \%$ 。 precision on each $\delta^{13} \mathrm{C}$ ) are required.

Isotopic composition of a contaminant fractionated during (bio)chemical transformation has been used to assess in situ biodegradation of organic contaminants in groundwater, since the isotopic enrichment of the residual pollutant is the best evidence to demonstrate (bio)degradation of these compounds. Isotope data are usually evaluated using the Rayleigh equation to estimate the extent of contaminant biodegradation or the first-order rate constants, assuming that the change in the average isotopic signature is subject to very robust fractionation. However, the Rayleigh equation is developed for homogeneous systems while in the subsurface, contaminants can migrate at different velocities due to physical heterogeneity. This approach leads to a systematic underestimation of the actual value due to the fact that it does not accommodate for the subsurface physical heterogeneity of field sites. A substantial systematic effect occurs especially for the quantification of the first-order rate constants (up to $50 \%$ underestimation of actual rate), while it is relatively small for the quantification of biodegradation $(<5 \%$ underestimation of actual degree of biodegradation) (54). Further implications for practical application of isotope studies in contaminated aquifers are the processes of natural attenuation that involve small isotope fractionation, such as mixing, sorption (55) or evaporation (56), and may confound quantification of a fractionating degradation processes using a simple streamline-Rayleigh approach (57). Although measured isotope ratios may, under special circumstances, overestimate the extent of degradation, they will not overestimate the extent of net removal from the aquifer. Thus, isotopic analysis can offer definitive demonstration of the degradation 
of these compounds in the environment, independent of mass loss due to non-degradative processes.

VOCs such as the chlorinated ethenes (58) and BTEX compounds (59) are strongly isotopically fractionated during degradation, and their isotopic analysis has the potential to yield information on what processes have affected the contaminant and to what extent these have occurred. In order for degradation to be reliably resolved from non-degradative subsurface processes, a VOC must be fractionated by more than $1.0 \%$.

Dissolved organic carbon (DOC) normally refers to naturally occurring organic substances dissolved in the sea, or in the rivers and lakes. It usually originates from the biodegradation of solid organic wastes and may itself be a groundwater contaminant. Due to its range of significant environmental effects in aquatic systems, DOC has extensively been investigated as an energy source, a mediator of nutrient and metal ion availability, and a regulator of photosynthesis through light attenuation (60). Mohammadzadeh et al. (61) applied CSIA to study the origin and biogeochemical reactions taking place in the DOC of groundwater from the municipal Trail Road Landfill (Ottawa, Canada) leachates. The difference in $\delta^{13} \mathrm{C}$ values for leachate acetate $(-10.7 \%$ o to $-16.9 \%$ o) and the bulk DOC (-24.7\%o) was used to distinguish landfill leachate derived DOC and identify biogeochemical reactions. The enrichment of $\delta^{13} \mathrm{C}$ in the acetate suggested that this biologically derived compound became a substrate for secondary biogeochemical reaction, likely methanogenesis.

Despite its relatively recent introduction as gasoline additive, methyl tert-butyl ether (MTBE) has become one of the most frequently detected groundwater contaminants. The differing isotopic enrichments found for aerobic (62) and anaerobic (63) biodegradation indeed reflect the underlying reaction mechanisms and therefore can be used as a powerful tool for the quantification of in-situ biodegradation of MTBE. The isotopic composition of MTBE at the site of a former industrial landfill in South America steadily changed from the source regions along the major contaminant plume $\delta^{13} \mathrm{C}(-26.4 \%$ o to $+40.0 \%$ o) and $\delta^{2} \mathrm{H}(-73.1 \%$ o to $+60.3 \%$ o), indicating substantial biodegradation (64). Coupled evaluation of two-dimensional compound-specific isotope data explained both carbon and hydrogen fractionation data in a consistent way and indicated anaerobic biodegradation of MTBE along the entire plume for the complex biogeochemical and hydrological regime at this site (Figure 3). Carbon and hydrogen KIE values, calculated for different potential reaction mechanisms, imply that anaerobic biodegradation of MTBE follows the nucleophilic second-order substitution $\left(\mathrm{S}_{\mathrm{N}} 2\right.$-type reaction) mechanism at that contaminated field site. Furthermore, obtained data suggested that additional removal process(es) such as evaporation contributed to the overall MTBE removal along the plume, a phenomenon that might also be significant for other field sites with tropic or subtropic climate and elevated groundwater temperatures $\left(25^{\circ} \mathrm{C}\right)$.

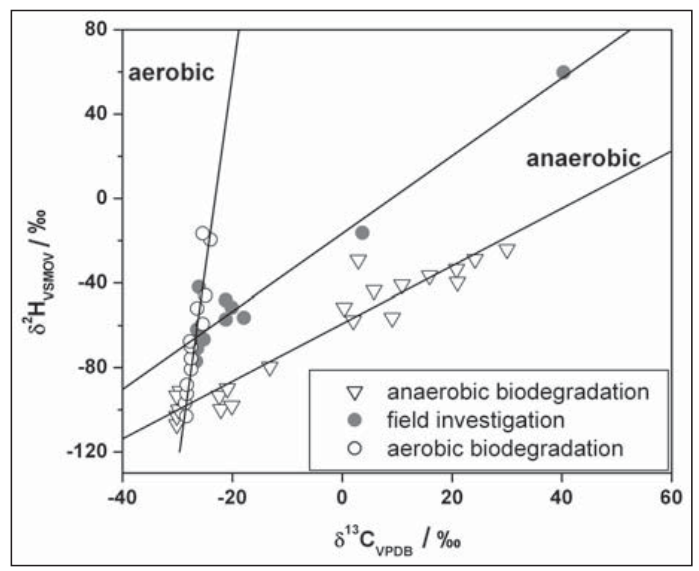

Figure 3 Plot of $\delta^{2} \mathrm{H}$ us. $\delta^{13} \mathrm{C}$ for MTBE in aerobic biodegradation in a batch experiment (62), anaerobic biodegradation at different field sites and field data from the major MTBE plume (63), after Zwank, et. al. (64)

\section{Chlorinated Aliphatic Hydrocarbons (CAHs)}

Chlorinated aliphatic hydrocarbons (CAHs), including the common solvents tetrachloroethene (PCE), trichloroethene (TCE), tetrachloromethane $\left(\mathrm{CCl}_{4}\right)$, trichloromethane $\left(\mathrm{CHCl}_{3}\right)$, and trichloroethane (TCA), are the most frequently detected groundwater contaminants due to their use for degreasing in dry cleaning. As solvents, they are known or suspected to be carcinogenic or mutagenic in humans. Natural attenuation of CAHs can be an important mechanism for groundwater remediation. It is difficult to determine the effectiveness of natural CAH attenuation from chemical analyses of groundwater samples because mixing, dispersion, and secondary reactions can mask the chemical evidence of attenuation. Under anaerobic conditions, the primary mechanism for the degradation of PCE and TCE in the environment is reductive dechlorination (65). A significant range in $\delta^{13} \mathrm{C}(34 \%)$ and $\delta^{37} \mathrm{C}(4.5 \%$ ) values obtained as initial isotopic ratios of these compounds from 
various manufacturers (29) can be useful for their environmental tracing. A much depleted $\delta^{2} \mathrm{H}$ (less than $-300 \%$ o) has strong implications for distinguishing dechlorination products (PCE to TCE) from different manufactured TCE (66). A study at Paducah Gaseous Diffusion Plant in western Kentucky, an industrial site extensively contaminated with CAHs, (67) demonstrated that stable $\mathrm{Cl}$ isotope ratios in both TCE and inorganic chloride in groundwater from an aerobic aquifer beneath provided a powerful tool for evaluating the effectiveness of natural attenuation. These data support a model in which partial TCE degradation occurred in relatively impermeable, clay-rich sediments above the aquifer, and little or no further degradation of TCE occurred within the aquifer. In addition, the evidence for anaerobic microbial reductive dechlorination of dissolved TCE in the source zone $\left(\delta^{13} \mathrm{C}=-25 \%\right.$ o to $-26 \%$ o) was the enrichment in $\delta^{13} \mathrm{C}$ value (-18\%o) in the residual contaminant of downgradient wells in respect to its original value (68).

\section{Aromatic Hydrocarbons}

PAHs have been studied intensely utilising $\delta^{13} \mathrm{C}$ analysis in sediment records (69) because they can be indicative of a variety of contaminant sources, such as petroleum spills or combustion processes, and are known to be carcinogenic. It was possible to relate to coal-derived PAHs released during different thermal conversion processes (combustion, pyrolysis, gasification) with the resulting $\delta^{13} \mathrm{C}(-24 \%$ o to $-25 \%$ o) values of the parent UK bituminous coals because their isotopic signatures were conserved in soil (70). Based on manufacturer-specific differences in $\delta^{13} \mathrm{C}$ values of BTEX compounds, isotope analysis may be valuable for identifying the origin of the dissolved contaminant in well-constrained field situations at concentrations from $0.1 \mu \mathrm{g} \mathrm{L}^{-1}$ to $100 \mu \mathrm{g} \mathrm{L}^{-1}$ (53). Nearly all evidence for BTEX and other hydrocarbon contaminations shows that carbon isotope fractionation is in the order of only a few \%o during biodegradation.

Although kinetic D/H isotope fractionation is two orders of magnitude greater than carbon isotope fractionation (71), CSIA for hydrogen isotope analysis is still more expensive and less precise than carbon isotope analysis. Relatively intensive changes in the hydrogen isotope ratio were used to quantify biodegradation of groundwater contaminated with benzene and ethylbenzene in an industrial site (Dow Benelux, the Netherlands) (72). Both benzene and ethylbenzene showed a small enrichment of ${ }^{13} \mathrm{C}(1 \%$ o to $2 \%$ o) in samples from the plume compared to samples from the source zone (Figure $4 \mathrm{a}$ and $4 \mathrm{~b}$, respectively). For this isotopic shift to become significant, a concentration reduction of approximately $80 \%$ - $90 \%$ is required, which means a degradation at a later stage. However, the results for $\delta^{2} \mathrm{H}$ showed a much stronger fractionating effect (fractionation of up to $27 \%$ for benzene and up to $50 \%$ for ethylbenzene) and provided conclusive confirmation for the biodegradation of benzene, even in downgradient samples that still have relatively high pollutant concentrations.

Stable carbon and nitrogen isotope ratios of products formed after the full oxidation of high explosive trinitrotoluene (TNT) in contaminated soil and groundwater were $4.2 \%$ and $15 \%$, respectively (73). This range of isotope ratios of TNT coming from five different sources reveals an excellent potential to trace its sources and migration of munition residuals in a complex environment.

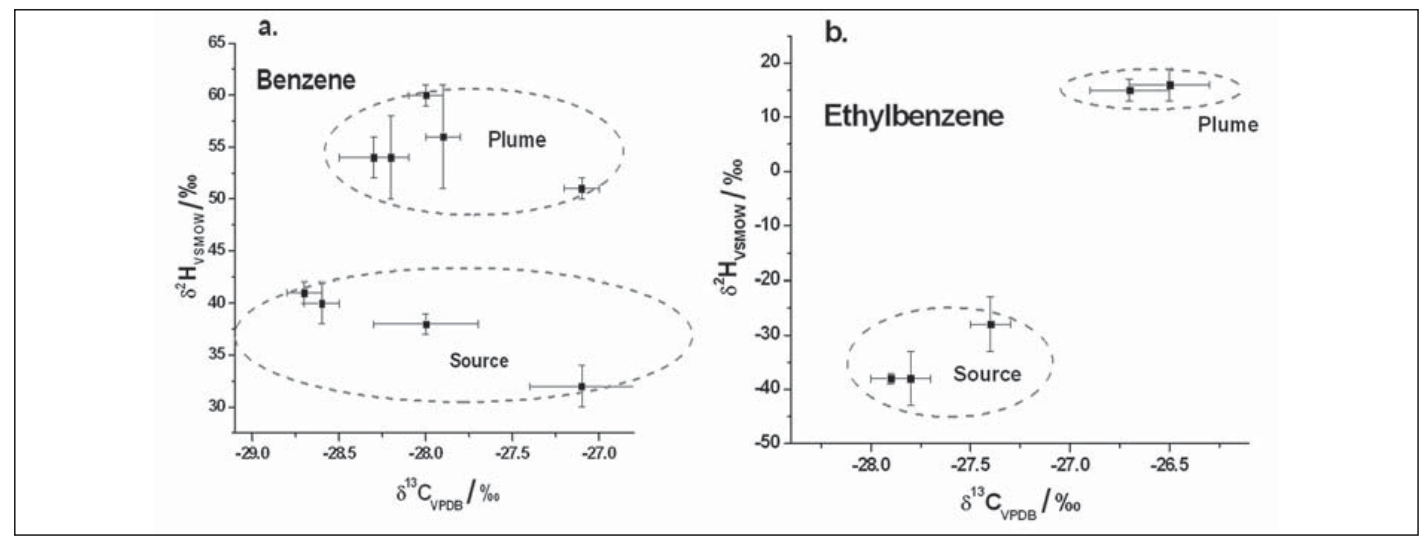

Figure 4 Stable isotope composition $\left(\mathrm{H}\right.$ and $\left.{ }^{13} \mathrm{C}\right)$ of benzene and ethylbenzene from the source zone and the contaminant plume (72) 


\section{CONCLUSION}

An increasing threat to groundwater supplies and surface water quality requires that the origin of specific compounds is determined and the flow of effluents traced in the natural environment. The application of environmental isotopes in pollutant migration studies makes it possible to trace potential sources, transport media, degradation products, and the final pool of natural and anthropogenic substances in the environment. This application depends on the ability of available techniques to reliably resolve differences in analysed isotopic ratios between samples. Analysis of stable isotope ratios of multiple elements in a single individual compound (e.g. ${ }^{2} \mathrm{H} /{ }^{1} \mathrm{H}$ with ${ }^{13} \mathrm{C} /{ }^{12} \mathrm{C}$ and ${ }^{37} \mathrm{Cl} /{ }^{35} \mathrm{Cl}$ or ${ }^{15} \mathrm{~N} /{ }^{14} \mathrm{~N}$ with ${ }^{18} \mathrm{O} /{ }^{16} \mathrm{O}$ ) should increase its ability to characterise the behaviour of environmental contaminant, which is critical for the understanding of reaction mechanism(s) and complex transport in natural systems and for establishing remediation strategies and responsibilities. Significant isotopic fractionation between residual organic component and degradation products caused by microbial degradation is direct evidence that bioremediation occurs in situations for which chemical measurements alone may provide insufficient or ambiguous data. This approach has made possible the use of stable isotope analysis in developing and interpreting bioremediation strategies for ecosystems that are contaminated with organic pollutants. The actual application, however, typically requires additional chemical (contaminant fate) and site-evaluation information (groundwater flow and transport processes) as well as an understanding of how and when isotopes fractionate. Studies using environmental isotopes can identify incipient pollution and provide early warning when chemical or biological indicators do not yet give cause for concern. Future research is primarily governed by the state-of-the-art in analytical instrumentation and method development.

\section{REFERENCES}

1. Lajtha K, Michener RH. Stable isotopes in ecology and environmental science. Oxford: Blackwell Sci Publication; 1994.

2. Ogrinc N, Lojen S, Faganeli J. A mass balance of carbon stable isotopes in organic-rich methaneproducting lacustrine sediment (Lake Bled, Slovenia). Glob Planet Change 2002:33;57-72.

3. Aggarwal PK, Gat JR, Klaus FO, Froehlich KFO, editors. Isotopes in the Water Cycle Past, Present and
Future of a Developing Science. Dordrecht: Springer; 2006.

4. Sidle WC. Environmental isotopes for resolution of hydrology problems. Environ Monit Assess 1998;52:389-410.

5. Clark ID, Fritz P. Environmental Isotopes in Hydrology. Boca Raton: Lewis; 1997.

6. Kendall C, McDonnell JJ, editors. Isotope Tracers in Catchment Hydrology. Amsterdam: Elsevier Science; 1998.

7. Cook PG, Herczeg AL. Environmental Tracers in Subsurface Hydrology. Boston: Kluwer Academic Publishers; 2000.

8. Martin GJ, Martin GG. NMR and MS stable isotope studies of fruit juice. In: Nagy S, Wade RI editors. Modern methods to detect adulteration of fruit juice beverages. Vol. 1. Auburndale, (FL): AG Science Inc.; 1995. p. 1-27.

9. Ashurst PR, Dennis MJ, editors. Food authentication. London: Blackie Academic and Professional; 1995.

10. Košir IJ, Kocjančič M, Ogrinc N, Jurkica Kidrič J. Use of SNIF-NMR and IRMS in combination with chemometric methods for the determination of chaptalisation and geographical origin of wines (the example of Slovenian wines). Anal Chim Acta 2001;429:195-206.

11. Jones PJH, Leatherdale ST. Stable isotopes in clinical research: safety reaffirmed. Clin Sci (Colch) 1991;80:277-80.

12. Klein PD, Graham DV. Minimum analysis requirements for the detection of Helicobacter pylori infection by the 13C Urea Breath Test. Am J Gastroentrol 1993;88:1865-9.

13. Emken EA. Stable isotope approaches, applications, and issues related to polyunsaturated fatty acid metabolism studies. Lipids 2001;36:965-73.

14. Miljevic N. Application of environmental isotopes in evaluation of pollutants. Crit Rev Anal Chem 2003;33:307-10.

15. Slater GF. Stable isotope forensics-when isotopes work. Environ Forensics 2003;4:13-23.

16. Galimov EM. The Biological Fractionation of Isotopes. Orlando: Academic Press; 1985.

17. Schmidt TC, Zwank L, Martin Elsner M, Berg M, Meckenstock RU, Haderlein SB. Compound-specific stable isotope analysis of organic contaminants in natural environments: a critical review of the state of the art, prospects, and future challenges. Anal Bioanal Chem 2004;378:283-300.

18. Richnow HH, Meckenstock RU, Reitzel LA, Baun A, Ledin A, Christensen TH. In situ biodegradation determined by carbon isotope fractionation of aromatic hydrocarbons in an anaerobic landfill leachate plume (Vejen, Denmark). J Contam Hydrol 2003;64:59-72.

19. Gat JR, Gonfiantini R, editors. Stable Isotope Hydrology: Deuterium and oxygen-18 in the water cycle. Vienna: IAEA; 1981. 
20. Brenna JT, Corso TN, Tobias HJ, Caimi RJ. Highprecision continuous-flow isotope ratio mass spectrometry. Mass Spectrom Rev 1997;16:227-58.

21. Confiantini R. Standards for stable isotope measurements in natural compounds. Nature 1978;271:534-6.

22. Coplen TB. More uncertainty than necessary. Paleoceanography 1996;11:369-70.

23. Krouse HR, Coplen TB. Reporting of relative sulfur isotope-ratio data. Pure Appl Chem 1997;69:293-5.

24. International Atomic Energy Agency (IAEA). IAEATECDOC-1247 New approaches for stable isotope ratio measurements. In: Proceedings of an Advisory Group Meeting Held in Vienna; 20-23 Sep 1999; Vienna, Austria. Vienna: IAEA; 2001.

25. Long A, Eastoe CJ, Kalfmann RS, Martin JG, Wirt L, Finley JB. High-precision measurement of chlorine stable isotope ratios. Geochim Cosmochim Acta 1993;57:2907-12.

26. Ballentine DC, Macko SA, Turekian VC, Gilhooly WP, Martincigh B. Compound specific isotope analysis of fatty acids and polycyclic aromatic hydrocarbons in aerosols: implications for biomass burning. Organic Geochem 1996;25:97-104.

27. Hilkert AW, Douthitt CB, Schluter HJ, Brand WA. Isotope ratio monitoring gas chromatography/mass spectrometry of $\mathrm{D} / \mathrm{H}$ by high temperature conversion isotope ratio mass spectrometry. Rapid Commun Mass Spectrom 1999;13:1226-30.

28. Macko SA, Uhle ME, Engel MH, Andrusevich V. Stable nitrogen isotope analysis amino acid enantiomers by gas chromatography/combustion/isotope ratio mass spectrometry. Anal Chem 1997;69:926-9.

29. Holt BD, Sturchio NC, Abrajano TA, Heraty LJ. Conversion of chlorinated volatile organic compounds to carbon dioxide and methyl chloride for isotopic analysis of carbon and chlorine. Anal Chem 1997;69:2727-33.

30. Zwank L, Berg M, Schmidt TC, Haderlein SB. Compound-specific carbon isotope analysis of volatile organic compounds in the low-microgram per liter range. Anal Chem 2003;75:5575-83.

31. Morrill PL, Lacrampe-Couloume G, Sherwood Lollar $B$, Dynamic headspace: a single-step extraction for isotopic analysis of $\mathrm{mg} / \mathrm{L}$ concentrations of dissolved chlorinated ethenes. Rapid Commun Mass Spectrom 2004;18:595-600

32. Hunkeler D, Chollet N, Pittet X, Aravena R, Cherry JA, Parker BL. Effect of source variability and transport processes on carbon isotope ratios of TCE and PCE in two sandy aquifers. J Contam Hydrol 2004;74:265-82.

33. Korom SF. Natural denitrification in the saturated zone: a review. Water Resour Res 1992;28:1657-68.

34. Kendall $C$, Aravena R. Nitrate isotopes in groundwater systems. In: Cook P, Herczeg AL, editors. Environmental tracers in subsurface hydrology. Dordrecht: Kluwer Academic Publishers; 2000. p. 261-97.
35. US Environmental Protection Agency (US EPA). National Primary Drinking Water Standards EPA 816F-02-013:2002. [displayed August 2003] Available at http://www.epa.gov/safewater/mcl.html\#inorganic.

36. Townsend MA, Young DP, Macko SA. Kansas case study applications of nitrogen-15 natural abundance method for identification of nitrate sources. J Hazard Sub Res 2003;4:1-22.

37. Silva SR, Kendall C, Wilkison DH, Ziegler AC, Chang CCY, Avanzino RJ. A new method for collection of nitrate from fresh water and the analysis of nitrogen and oxygen isotope ratios. J Hydrology 2000;228:22-36.

38. Fukada T, Hiscock KM, Dennis PF, Grischek T. A dual isotope approach to identify denitrification in groundwater at a river-bank infiltration site. Water Res 2003;37:3070-8.

39. Kendall C. Isotope tracers in catchment hydrology. [displeyed 1 March 1999]. Available at http:// wwwrcamnl.wr.usgs.gov/isoig/isopubs/ithfig169.html.

40. Bachinski DJ. Bond strength and sulfur isotopic fractionation in coexisting sulfides. Econ Geol 1969;64:56-65.

41. Ohmoto H, Rye RO. Isotopes of sulfur and carbon. In: Barnes HL, editor. Geochemistry of Hydrothermal Ore Deposits. $2^{\text {nd }}$ ed. New York (NY): John Wiley $E$ Sons; 1979. p. 509-67.

42. Thode HG, Monster J. Sulfur isotope geochemistry of petroleum, evaporites, and ancient seas. In: Young A, Galley JE, editors. Fluids in subsurface environments. Am Assoc Petro Geol Mem 1965;4:367-77.

43. Zielinski RA, Johnson CA, Adams JI. Use of sulfur isotopes to monitor dissolved sulfate derived from a fly ash emplacement site, north-central Colorado. In: International Ash Utilization Symposium and World of Coal Ash Symposium. 11-15 April 2005. Lexington, KY. [displeyed 25 April 2007]. Available at http://whocares. caer.uky.edu/wasp/AshSymposium/AshLibraryAuthors. asp\#Z

44. Smith JW, Batts BD. The distribution and isotopic composition of sulfur in coal. Gechim Cosmochim Acta 1974;38:121-33.

45. Haefner RJ. A sulfur-isotope mixing model to trace leachate from pressurized fluidized bed combustion byproducts in an abandoned-coal-mine setting. Fuel 2001;80:829-36.

46. Pluta I. Identification of mine waters in the southern Upper Silesian Coal Basin (Poland) by $\delta^{34} S$ and $\delta^{18} \mathrm{O}$ in sulphates. In: $7^{\text {th }}$ International Mine Water Association Congress; 1115 Sep 2000; Katowice - Ustron, Poland. 2000. p. 604-8. [displeyed 5th March 2007]. Available at http://www.imwa. info/publications/congress_2000.htm

47. Krouse HR. Sulfur isotopes in our environmental. In: Fritz P, Fontes JCh, editors. Handbook of Environmental Isotope Geochemistry. New York (NY): Elsevier; 1980. p. $435-71$. 
48. Thode HG. Stable isotopes in assessment of natural and anthropogenic sulfur in the environmental. In: Krouse HR, Grinenko VA, editors. Stable Isotopes: Natural and Anthropogenic Sulphur in the Environment, SCOPE 43. Chichester: John Wiley and Sons;1991. p. 2-25.

49. O'Malley VP, Abrajano TA, Hellou J. Stable carbon isotopic apportionment of individual polycyclic aromatic hydrocarbons in St. John's Harbour, Newfoundland. Environ Sci Technol 1996;30:634-9.

50. Drenzek NJ, Eglinton TI, Wirsen CO, May HD, Wu Q, Sowers KR, Reddy CM. The absence and application of stable carbon isotopic fractionation during the reductive dechlorination of polychlorinated biphenyls. Environ Sci Technol 2001;35:3310-3.

51. Smallwood BJ, Philp RP, Burgoyne TW. The use of stable isotopes to differentiate specific source markers for MTBE. Environ Forensics 2001;2:215-21.

52. Jendrzejewski N, Eggenkamp HGM, Coleman ML. Characterization of chlorinated hydrocarbons from chlorine and carbon isotopic compositions: Scope of application to environmental problems. Appl Geochem 2001;16:1021-31

53. Dempster HS, Sherwood Lollar B, Feenstra S. Tracing organic contaminants in groundwater: A new methodology using compound-specific isotopic analysis. Environ Sci Technol 1997;31:3193-7.

54. Abe Y, Hunkeler D. Does the Rayleigh equation apply to evaluate field isotope data in contaminant hydrogeology? Environ Sci Technol 2006:40:1588-96.

55. Slater GF, Ahad JME, Sherwood Lollar B, Allen-King $\mathrm{R}$, Sleep B. Carbon isotope effects resulting from equilibrium sorption of dissolved VOCs. Anal Chem 2000;72:5669-72.

56. Harrington RR, Poulson SR, Drever JI, Colberg PJS, Kelly EF. Carbon isotope systematics of monoaromatic hydrocarbons: Vaporization and adsorption experiments. Org Geochem 1999;30:765-75.

57. Kopinke FD, Georgi A, Richnow HH. Comment on "New evaluation scheme for two-dimensional isotope analysis to decipher biodegradation processes: Application to groundwater contamination by MTBE". Environ Sci Technol 2005;39:8541-2.

58. Bloom Y, Aravena R, Hunkeler D, Edwards EA, Frape SK. Carbon isotope fractionation during microbial dechlorination of trichloroethene, cis-1,2dichloroethene, and vinyl chloride: Implications for assessment of natural attenuation. Environ Sci Technol 2000;34:2768-72.

59. Hunkeler D, Andersen N, Aravena R, Bernasconi M, Butler BJ. Hydrogen and carbon isotope fractionation during aerobic biodegradation of benzene. Environ Sci Technol 2001;35:3462-7.

60. Christensen JB, Jensen DL, Gron C, Filip Z, Christensen $\mathrm{TH}$. Characterization of the dissolved organic carbon in landfill leachate polluted groundwater. Water Res 1998:32:125-35.
61. Mohammadzadeh T, Clark I, Marschner M, St-Jean G. Compound Specific Isotopic Analysis (CSIA) of landfill leachate DOC components. Chem Geol 2005;218:3-13.

62. Gray JR, Lacrampe-Couloume G, Deepa G. Carbon and hydrogen isotopic fractionation during biodegradation of methyl tert-butyl ether. Environ Sci Technol 2002;36:1931-8.

63. Kuder T, Philp RP, Kolhatkar R, Wilson JT, Allen J. Application of stable carbon and hydrogen isotopic techniques for monitoring biodegradation of MTBE in the field. In: Proceedings of the 2002 Petroleum Hydrocarbons and Organic Chemicals in Ground Water: Prevention, Detection and Restoration, NGWA and API. 6-8 Nov 2002. Atlanta, GA. Westerville: National Ground Water Association; 2002. p. 371-81.

64. ZwankL, Berg M, Elsner M, Schmidt TC, Schwarzenbach RP, Haderlein SB. A new evaluation scheme for twodimensional isotope analysis to decipher biodegradation processes: Application to groundwater contamination by MTBE. Environ Sci Technol 2005;39:1018-29.

65. Vogel TM, Criddle CS, McCarty PM. Transformations of halogenated aliphatic compounds. Environ Sci Technol 1987;21:722-36.

66. Shouakar-Stash O, Frape SK, Drimmie RJ. Stable hydrogen, carbon and chlorine isotope measurements of selected chlorinated organic solvents. J Contam Hydrology 2003;60:211-28.

67. Sturchio NC, Clausen JL, Heraty LJ, Huang L, Holt BD, Abrajano TA. Chlorine isotope investigation of natural attenuation of trichloroethene in an aerobic aquifer. Environ Sci Technol 1998;32:3037-42.

68. Sherwood Lollar B, Slater GF, Sleep B, Witt M, Klecka GM, Harkness M, Spivack J. Stable carbon isotope evidence for intrinsic bioremediation of tetrachloroethene and trichloroethene at area 6, Dover Air Force Base. Environ Sci Technol 2001;35:261-9.

69. LaFlamme RE, Hites RA. The global distribution of polycyclic aromatic hydrocarbons in recent sediments. Geochim Cosmochim Acta 1978;42:289-303.

70. McRae C, Sun CG, Snape CE, Fallick AE, Taylor D. $\delta^{13} \mathrm{C}$ values of coal-derived PAHs from different processes and their application to source apportionment. Org Geochem 1999;30:881-9.

71. Coleman DD, Risatti B, Schoell M.Fractionation of carbon and hydrogen isotopes by methane-oxidizing bacteria. Geochim Cosmochim Acta 1981;45:1033-7.

72. Mancini SA, Lacrampe-Coulome G, Jonker H. Van Breukelen BM, Groen J, Volkering F, Sherwood Lollar B. Hydrogen isotope enrichment: an indicator of biodegradation at a petroleum hydrocarbon contaminated field site. Environ Sci Technol 2002:36:2464-70.

73. Coffin RB, Miyares PH, Kelley CA, Cifuentes LA, Reynolds CM. Stable carbon and nitrogen isotope analysis of TNT: two-dimensional source identification. Environ Toxicol Chem 2001;20:2676-80. 


\section{Sažetak}

\section{POTENCIJALNA UPOTREBA IZOTOPA VAŽNIH ZA OKOLIŠ U ISPITIVANJU MIGRACIJE ONEČIŠĆUJUUĆIH TVARI}

Cilj ovog rada je da se prikaže korištenje podataka analize prirodne obilnosti stabilnih izotopa (vodika, ugljika, dušika, kisika i klora) kao alata za dobivanje važnih informacija o porijeklu onečišćujućih tvari, doprinosu različitih multikomponentnih onečišćivača, karakterizaciji njihova kompleksnog transporta (brzine i mehanizma) i praćenja uspjeha remedijacije onečišćenih mjesta. Izotopski sadržaji onečišćujućih tvari koriste se kao traseri za određivanje njihovih izvora, dok se izotopsko frakcioniranje može iskoristiti za kvantitativnu procjenu toka procesa kao što je biodegradacija. Takav nov izotopski pristup je pouzdan i nudi više informacija od tradicionalnih tehnika kontrole putovanja onečišćivala, napose nakon odlaganja opasnog otpada na zemljištu. Za vrijeme biodegradacije nekog organskog spoje molekule koje sadržavaju lake izotope lakše se degradiraju, a dio težih izotopa u supstratu se povećava, što upućuje na mikrobiološku ulogu u biokemijskom ciklusu. Kako je izotopsko frakcioniranje proporcionalno degradaciji zavisno od tipa onečišćenja, korištenjem podataka mjerenja izotopskih odnosa može se procijeniti mikrobiološka degradacija od $50 \%$ do $99 \%$ od početne koncentracije.

KLJUČNE RIJEČI: biodegradacija, rudnik ugljena, dušik, organske onečišćujuće tvari, stabilni izotopi, sumpor

CORRESPONDING AUTHOR:

Nada Miljević

Vinča Institute of Nuclear Sciences

POB 522, 11001 Belgrade, Serbia

E-mail: emiljevi@vin.bg.ac.yu 